\title{
Penentuan Posisi Sudut Matahari Menggunakan ANFIS dalam Aplikasi Tracker Panel Surya
}

\author{
Muhammad Irfan*, Ilham Pakaya, dan Amrul Faruq \\ Jurusan Teknik Elektro, Fakultas Teknik, Universitas Muhammadiyah Malang \\ *Corresponding author, e-mail: irfan@umm.ac.id
}

\begin{abstract}
Abstrak - Panel surya memiliki kendala pada daya keluaran yang tidak cukup besar dan sangat tergantung oleh kondisi alam. Daya panel surya sangat tergantung dari intensitas cahaya matahari yang diterima dan suhu lingkungan sekitar. Agar mendapatkan daya keluaran panel surya yang maksimal dibutuhkan perangkat tambahan yang disebut tracker matahari. Penelitian ini memiliki kontribusi dalam meningkatkan daya keluaran panel surya dengan mengarahkan panel surya tegak lurus dengan cahaya matahari. Penggunaan penelitian ini sangat bermanfaat dalam penerapan aplikasi tracker multiaxis dari matahari. Dengan mengetahui sudut terbitnya matahari pada setiap pagi hari dan sudut edar sampai dengan terbenam, tracker akan bekerja dengan cepat sehingga energi yang digunakan untuk pergerakan sangat kecil. Sudut referensi yang dihasilkan oleh algoritma pelatihan ANFIS, lebih akurat karena data hasil perhitungan akan dikonfirmasi kembali oleh sensor. Serta sistem ini dapat bekerja secara offline, tanpa terhubung dengan pusat data, sehingga dapat digunakan pada area terpencil atau terisolasi.
\end{abstract}

Kata Kunci : Posisi Sudut Matahari, MPPT, ANFIS, Panel Surya

\begin{abstract}
Solar panels have constraints on output power that are not large enough and they are highly depend on natural conditions. Solar panel power depends on the intensity of sunlight received and the temperature of the surrounding environment. In order to get the maximum output power of the solar panel, an additional device called the solar tracker is needed. This research has contributed to increasing the output power of solar panels by directing solar panels perpendicular to sunlight. The use of this research is very useful in the application of the multi-axis tracker application from the sun. By knowing the rising angle of the sun every morning and the circulation angle to sunset, the tracker will work quickly so that the energy used for movement is very small. The reference angle generated by the ANFIS training algorithm is more accurate because the calculated data will be confirmed again by the sensor. And this system can work offline, without being connected to a data center, so it can be used in remote or isolated areas.
\end{abstract}

Keywords : Sun Tracking System, MPPT, ANFIS, Solar Panels

\section{Pendahuluan}

Panel surya adalah perangkat yang mengubah energi matahari menjadi energi listrik menggunakan bahan semikonduktor. Sistem panel surya dapat menghasilkan energi listrik langsung dari matahari. Panel surya memiliki kendala pada daya keluaran yang tidak cukup besar dan itu sangat tergantung pada kondisi alam. Daya energi panel surya tergantung pada intensitas sinar matahari yang diterima dan suhu lingkungan sekitarnya. Untuk mendapatkan daya output maksimum dari panel surya, diperlukan perangkat tambahan yang disebut pelacak surya. Pelacak matahari bekerja dengan menggerakkan panel surya untuk mendapatkan posisi tegak lurus terhadap matahari [1]. Intensitas cahaya yang diterima sangat mempengaruhi voltase dan arus yang dihasilkan oleh panel surya.

Meningkatkan dan mengoptimalkan efisiensi dalam penyerapan energi surya perlu dilakukan, sistem pelacakan matahari adalah salah satu komponen penting dalam sistem energi surya. Berdasarkan konstruksi, ada dua konstruksi utama pada sistem pelacakan matahari, yaitu sumbu tunggal (poros tunggal) [2] dan poros ganda panel surya [3]. Mekanisme pelacakan surya poros tunggal dapat meningkatkan efisiensi penyerapan energi surya hingga $32 \%$ dari sistem panel surya permanen. Sistem konstruksi juga memiliki kompleksitas yang lebih rendah dan biaya yang lebih rendah, sehingga sistem ini sangat baik untuk diterapkan pada berbagai aplikasi. Di sisi lain, dengan mengabaikan kompleksitas konstruksi dan 
pembiayaannya [4], sistem pelacakan surya poros ganda memiliki efisiensi yang lebih tinggi hingga $40 \%$ dibandingkan dengan konstruksi panel surya tetap.

Proses pelacakan posisi matahari membutuhkan metode yang dapat memperkirakan dan mendeteksi posisi matahari bersama dengan panel surya. Secara umum, ada dua jenis utama metode pelacakan untuk memperkirakan posisi matahari. Pertama, perhitungan astronomi berdasarkan sistem pelacakan matahari. Sistem ini memperkirakan pergerakan matahari bersama dengan pergerakan bumi berdasarkan perhitungan astronomi dengan posisi input dari tempat generator di bumi, dan memperkirakan posisi periodik matahari dengan waktu. Keuntungan utama dari sistem ini adalah bahwa sistem ini tahan terhadap gangguan eksternal, seperti cuaca yang bervariasi. Namun, metode ini hanya memperkirakan posisi relatif matahari, tanpa umpan balik langsung. Kelemahan dari metode ini adalah bahwa sistem harus terhubung ke pusat manajemen data.

Metode kedua adalah sistem pelacakan matahari menggunakan sensor. Sistem ini menggunakan sensor cahaya untuk secara langsung memperkirakan dan melacak posisi matahari berdasarkan kondisi aktual [5]. Ketika sensor dapat mendeteksi matahari dengan sempurna, sistem ini dapat memperkirakan posisi matahari dengan tepat. Namun, sistem ini sangat tergantung pada kualitas hasil deteksi. Ini berhubungan secara signifikan dengan kondisi cuaca seperti hari-hari cerah, berawan dan juga waktu (misalnya pagi, siang dan malam).

Ada sejumlah studi sistem pelacakan mataharisurya yang melibatkan algoritma mereka yang telah melaporkan untuk memaksimalkan output sistem surya [6], [7] dan mengoptimalkan kinerja sistem pembangkit listrik tenaga surya [8]. Perhatian yang lebih baru telah difokuskan pada kuantitas daya yang dihasilkan oleh hibrida grid-photovoltaic dan sistem konversi energi angin seperti yang diusulkan oleh [9]. Selain itu, penting untuk mengoptimalkan sistem pelacak untuk menyesuaikan jumlah matahari-matahari yang diterima. Seperti yang dipelajari dalam [10], algoritma kontrol telah dikembangkan untuk meningkatkan kinerja dan keandalan pelacak surya dua sumbu. Hasilnya menunjukkan suatu sistem dapat meningkatkan energi yang dikumpulkan dengan memperbaiki teknik penentuan posisi. Namun, kontrol mekanisme ini masih memilki peluang untuk mengoptimalkan konsumsi energi terendah dengan produksi energi maksimum.

Dengan menggabungkan kedua metode ini, sebuah studi akan dilakukan mengenai penentuan sudut referensi panel surya dengan matahari menggunakan metode ANFIS dan penggunaan sensor sebagai posisi penyempurnaan. Hasil penentuan sudut dalam penelitian ini ditunjukkan oleh peningkatan nilai radiasi. Hasil penelitian ini diharapkan, dapat diterapkan pada panel surya yang dipasang di daerah terpencil yang tidak memiliki akses ke posisi data secara real time. Untuk penyelidikan lebih lanjut, penelitian ini akan fokus untuk mendapatkan data iradiasi sebagai pelatihan intensitas selama setahun. Diskusi ekstensif tentang kinerja model pada output panel surya setelah mengubah arah sudut juga dibahas.

\section{Studi Pustaka}

Sebuah sistem tracker matahari dengan biaya rendah diimplementasikan menggunakan kombinasi antara timer dan sensor cahaya (LDR). Pada sistem ini, posisi matahari, mulanya diestimasi menggunakan kalkulasi sederhana dengan timer. Jalur matahari diasumsikan jalur setengah lingkaran dengan posisi matahari terbit pada 0 derajat dan matahari terbenam 180 derajat dari arah timur ke barat, ditunjukkan pada Gambar 1.

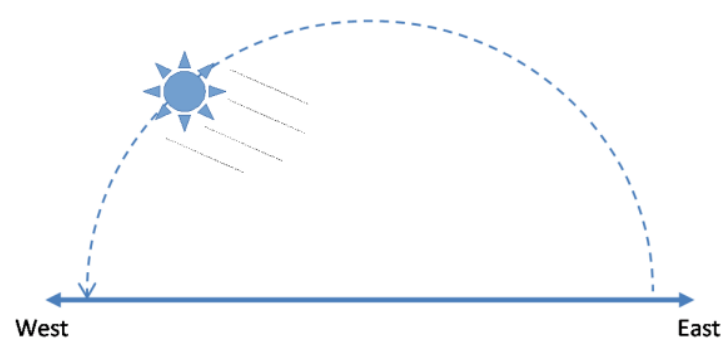

Gambar 1. Pengansumsian Sederhana Pada Jalur Matahari

Pergerakan sudut matahari per detik secara sederhana dihitung dengan membagi jalur sudut seluruhnya dengan periode pergerakan matahari (diasumsikan mulai dari $06.00 \mathrm{~s} / \mathrm{d}$ 18.00). Sehubungan dengan pergerakan bumi dengan posisi matahari, pelacakan matahari dapat direpresentasikan oleh dua sudut berbeda dengan melihat koordinat tertentu di bumi yaitu sudut azimuth dan sudut elevasi. Ilustrasi ini dapat dilihat pada Gambar 2. 


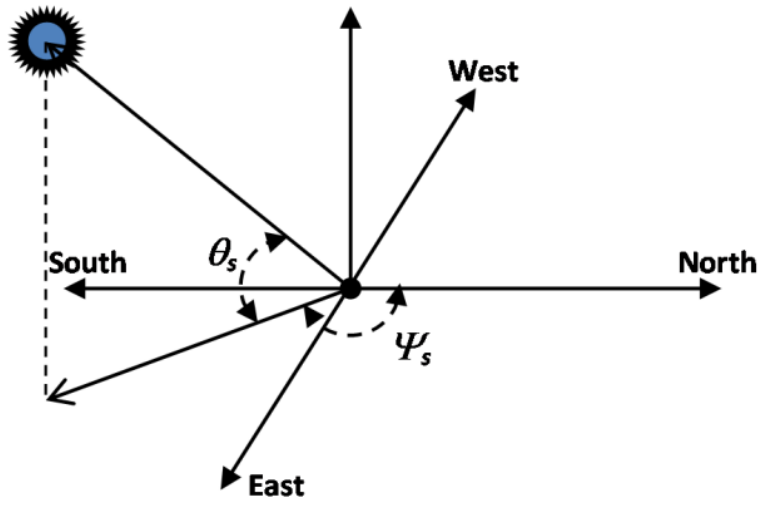

Gambar 2.Ilustrasi Sudut Azimut Dan Sudut Elevasi Pada Sistem Penempatan

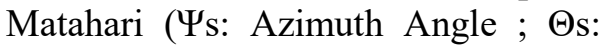
Elevation Angle)

Guna meningkatkan optimalitas pada penyerapan energi matahari, sebuah mekanisme pelacakan matahari poros ganda, seperti ditunjukan pada Gambar 3, dibutuhkan untuk mengatur sudut azimuth dan sudut elevasi pada panel collector. Hal ini dapat meningkatkan penyerapan energi hingga $10 \%$ lebih tinggi dari pada konstruksi panel poros tunggal.

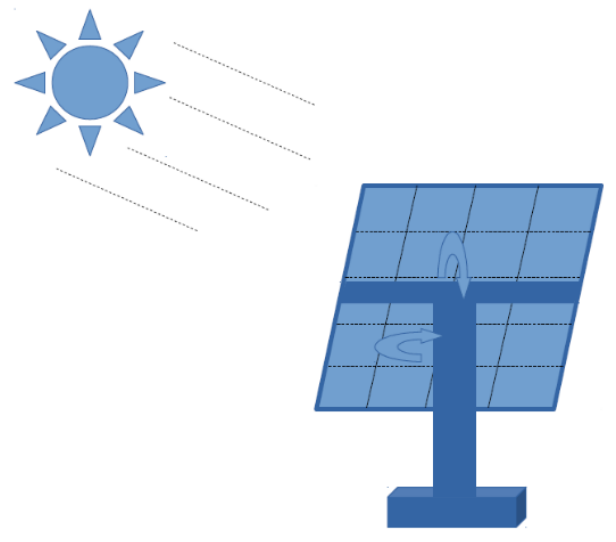

Gambar 3. Ilustrasi Umum Pada Panel Surya Poros Ganda

\subsection{Adaptive Neuro Fuzzy Inference System (ANFIS)}

J.-S.R. Jang [11] mengusulkan sebuah adaptive network-based fuzzy inference system (ANFIS) berdasarkan model T-S diawal tahun 1990an. Algoritma ini adalah sebuah tipe baru dari neural network, yang fitur utamanya adalah campuran dari logika fuzzy dan neural network. Model fuzzy oleh Sugeno, juga dikenal sebagai TSK fuzzy model, diajukan oleh Takagi, Sugeno dan Kang, yaitu sebuah metode sistematik untuk menghasilkan aturan fuzzy berdasarkan input-output data yang diberikan. Karena aturan dari linearitas tergantung pada sistem variabel input, model Sugeno adalah sebuah kontroller multivariabel ideal, yang dapat diaplikasikan untuk nonlinear dynamic systems dengan berbagai kondisi operasi. Diagram tipikal struktur dari ANFIS diperlihatkan pada Gambar 4.

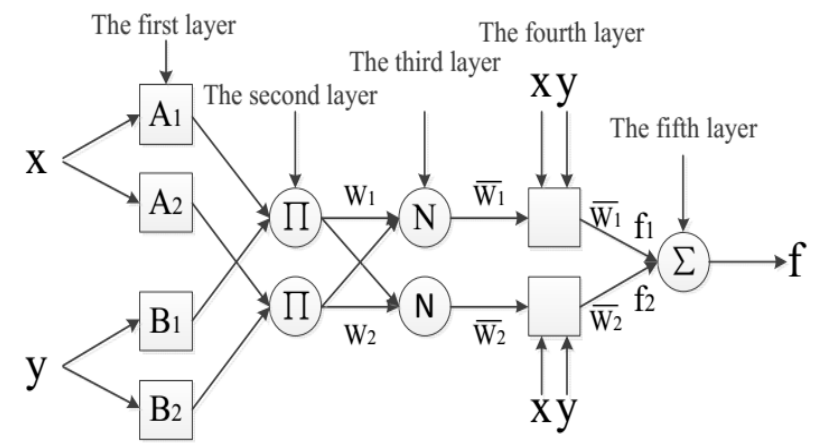

Gambar 4. Diagram Struktur ANFIS

Diasumsikan bahwa fuzzy inference system memiliki dua input $x$ dan $y$, output tunggal $f$. Untuk urutan pertama dari model fuzzy Sugeno, rule/aturan umumnya ditetapkan dengan dua fuzzy if-then, aturan ditunjukan sebagai berikut.

Rule 1: jika x adalah A1 dan y adalah B1, maka:

$$
f_{1}=p_{1} x+q_{1} y+r_{1}
$$

Rule 2: jika x adalah A2 dan y adalah B2, maka:

$$
f_{2}=p_{2} x+q_{2} y+r_{2}
$$

\section{Metode Penelitian}

Algoritma tracker mampu mendeteksi perubahan masukan irradiasi dan temperatur yang bervariasi. Variasi masukan PV tersebut diproses dalam sistem neuro-fuzzy atau neuro-fuzzy network (NFN) sehingga didapat keluaran berupa tegangan acuan pada daya maksimum. Secara umum untuk mendapatkkan nilai daya puncak PV minimal harus didapatkan beberapa data temperatur (Ta) dan irradiasi (Ga). Dengan dua besaran ini maka akan didapatkan daya puncak PV yang nantinya dijadikan acuan untuk menentukan besar tegangan acuan Vref boost konverter.

Gambar 5 menyajikan diagram blok algoritma tracker. Masukan suhu dan irradiasi diolah oleh ANN dan didapat keluaran Vref. Tegangan referensi menjadi acuan kerja proportional 
integratif kontroler PI kontroler yang akan menjaga PV bekerja pada tegangan Vref dengan cara mengatur besar duty cycle $\mathrm{D}^{*}$ boost konverter. Sementara Gambar 6 memperlihatkan desain sistem PV yang dikerjakan dalam penelitian ini.

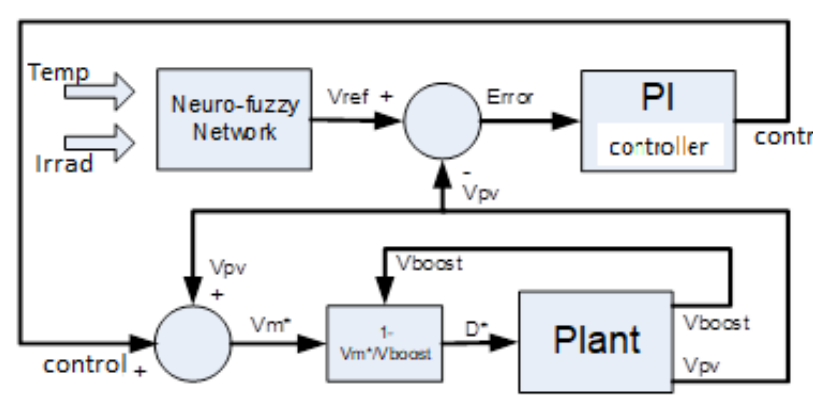

Gambar 5. Diagram blok Maxiumum Power Point Traking (MPPT).

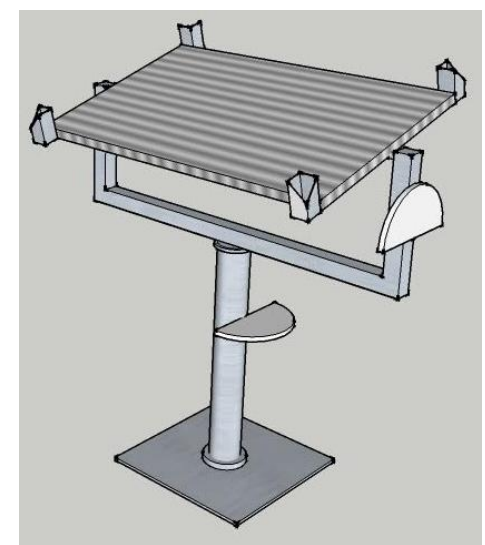

Gambar 6. desain MPPT yang diusulkan

Fuzzy-classifier yang digunakan pada penelitian ini adalah fuzzy rule-based classifiers yang dikembangkan oleh Kuncheva [12]. Fuzzy rulebased classifiers yang memiliki prinsip sama dengan fuzzy-control dan merupakan fuzzy if-then sistem. Dalam penelitian ini membership function tidak didapat dari proser learning. Membership function didapat dari data dan pengalaman yang telah ada. Tabel 1 dan Gambar 7 menunjukkan basis aturan fuzzy yang digunakan dalam penelitian ini.

Tabel 1. Fuzzy rule-base yang digunakan

\begin{tabular}{|l|l|l|l|}
\hline \multirow{2}{*}{ Suhu } & \multicolumn{3}{|c|}{ Irradiasi } \\
\cline { 2 - 4 } & Berawan & \multicolumn{1}{|c|}{ Normal } & \multicolumn{1}{c|}{ Cerah } \\
\hline Dingin & Kelas 2 & Kelas 3 & Kelas 3 \\
\hline Hangat & Kelas 1 & Kelas 2 & Kelas 3 \\
\hline Panas & Kelas 1 & Kelas 1 & Kelas 2 \\
\hline
\end{tabular}
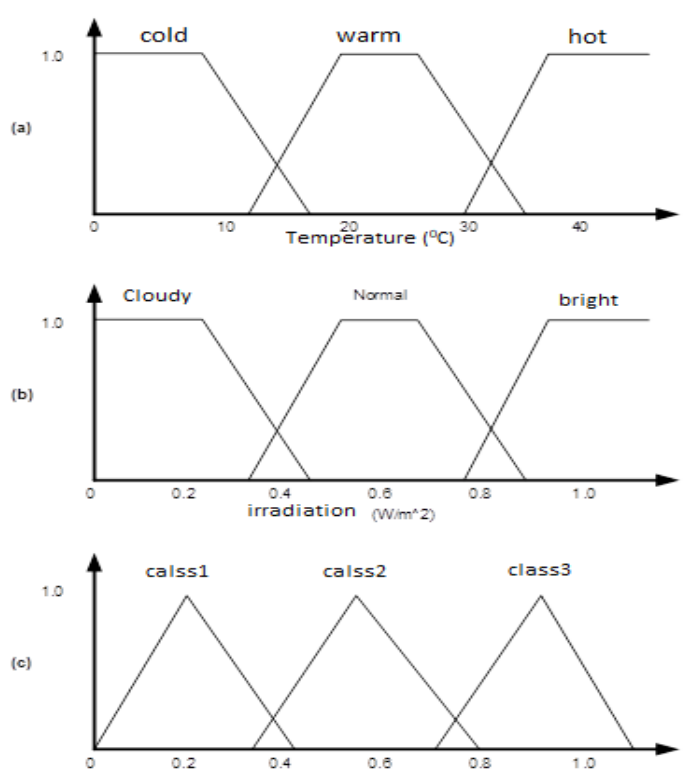

Gambar 7. Input dan fungsi keanggotaan fuzzy classifier

Kedua komponen fuzzy tersebut membentuk spectrum yang membagi masukan menjadi tiga kelas. Gambar 8 menyajikan pola pembagian kelas. Kelas 1 berwarna biru, kelas 2 berwarna hijau, dan kelas 3 berwarna kuning.

Dalam penelitian ini digunakan ANN yang memiliki arsitektur Multi-layered Percepton Neural Network (MLPNN). ANN memiliki dua masukan suhu, irradiasi dan satu keluaran berupa tegangan referensi Vref. Untuk mengolah data masukan menjadi sebuah keluaran, AAN harus mengalami pelatihan atau training. Dalam proses pelatihan ANN dibutuhkan data pelatihan. Jumlah training data ANN tergantung dari jumlah masukan dan keluarannya. Jadi, untuk ANN yang memiliki dua masukan dan dua keluaran memiliki 3 macam training data.

Dalam penelitian ini jumlah lapisan MLPNN sebanyak dua layer. Jumlah hidden neuron sebanyak sebelas neuron. Parameter pelatihan training set sebesar $70 \%$, validation set sebesar $15 \%$, dan testing set sebesar $15 \%$. Pelatihan dilakukan dengan menggunakan algoritma Levenberg-Marquardt, dengan fungsi peformansi Mean Square Error MSE. 


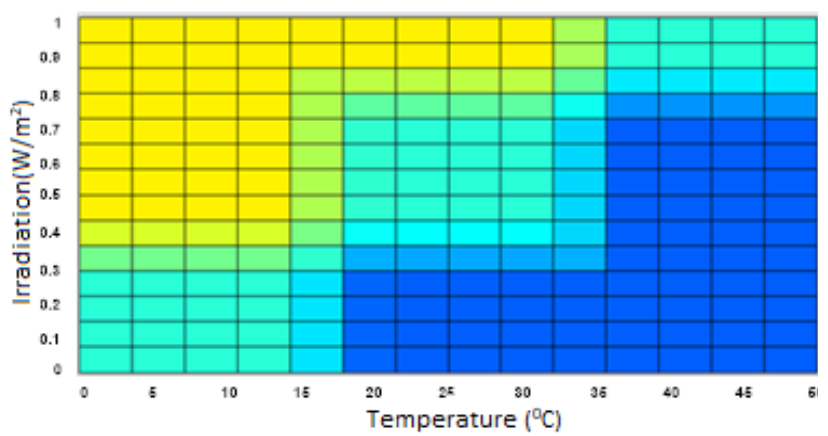

Gambar 8. Pola pembagian kelas pada fuzzy rulebased classifiers

\section{Hasil dan Pembahasan}

Gambar 9 menyajikan fungsi peformansi pelatihan terhadap epoch atau banyak iterasi pelatihan. MSE terkecil terjadi pada iterasi ke-150 dengan nilai 7,20*10-1 dengan nilai regresi $\mathrm{R}$ 0.999948*10-1 pada ANN. Regresi merupakan tingkat kedekatan masukan dan keluaran pada ANN yang sudah terlatih.

Sementara pada Gambar 10 digunakan sebagai referensi untuk pengambilan data daya dan perhitungan efisiensi dan sistem photovoltaic (PV). Dengan referensi di atas, dapat dipahami bahwa daya di setiap bagian, efisiensi sistem dan kinerja. Untuk mengetahui perbedaan dalam daya yang dihasilkan, ia menggunakan berbagai tahanan sebagai beban pada PV untuk sistem non-MPPT. Dari gambar tersebut dapat diamati bahwa dalam sistem PV yang tidak menggunakan MPPT, daya yang dihasilkan tidak selalu pada daya maksimum ketika dimuat dengan nilai tahanan yang berbeda. Hal ini tentunya akan mengurangi efisiensi sistem. Dalam sistem yang menggunakan MPPT di dalamnya, PV terpaksa bekerja pada tegangan optimalnya, sehingga daya maksimum selalu tercapai.

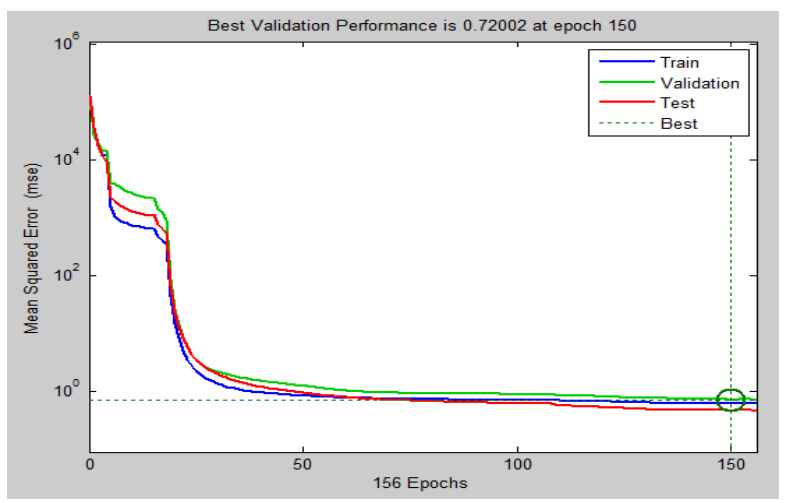

Gambar 9. Performa pelatihan ANN

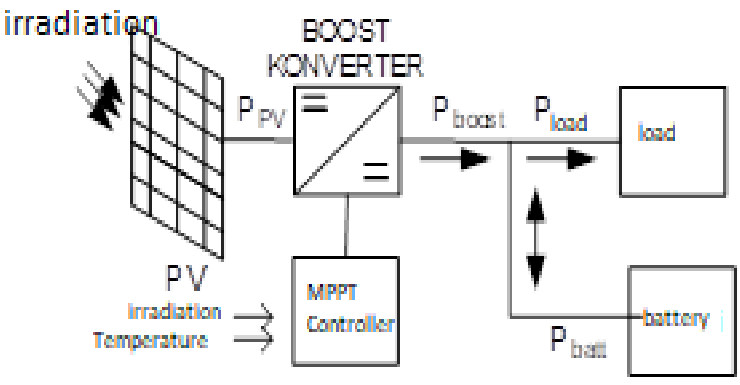

Gambar 10. Konfigurasi sistem solar panel

Gambar 11 menunjukkan hasil simulasi sistem PV yang ditampilkan. Hasil ini menampilkan jumlah daya yang dipasok oleh PV dan daya yang dikeluarkan oleh boost converter. Daya yang diambil adalah jumlah daya yang dihasilkan dari perkalian arus dengan tegangan pada iradiasi 1000 $\mathrm{W} / \mathrm{m}^{2}$ dan suhu 350C. Pada amber 4. 16 dapat dilihat bahwa daya rata-rata pada keadaan stedy adalah sekitar 18884,46 W, nilainya hampir sama jika dibandingkan dengan daya puncak 18884,5 Watt. Gambar 10 juga menggambarkan jumlah daya yang keluar dari konverter boost. Jumlah daya yang diambil dari arus rata-rata dikalikan dengan tegangan rata-rata. Pada Gambar 11. 16, dapat dilihat rata-rata daya pada boost converter adalah 18711, 64 Watt. Dari nilai daya output konverter dan daya $\mathrm{PV}$, daya rata-rata yang hilang dalam boost converter adalah 172, 82 Watt.

Lamanya boost konverter mencapai steady state bergantung pada besar Induktor yang dipakai pada boost converter. Nilai induktansi yang digunakan mempengaruhi waktu pengisian induktor untuk mencapai arus steady state. Semakin tinggi nilai induktansi, maka semakin lama waktu menuju steady state. Sebaliknya ketika nilai induktansi dikurangi, maka waktu menuju steady state akan semakin kecil. Nilai induktansi juga harus di sesuaikan dengan nilai batas riple arus yang timbul mengingat sumber daya yang digunakan membutuhkan ripple arus yang kecil.

\subsection{Tingkat Keandalan Sistem PV}

Tingkat keandalan pada sistem PV dapat dinilai dari beberapa aspek, antara lain yang telah kita bicarakan sebelumnya yaitu akurasi dan efisiensi. Seperti apa yang telah diurakan sebelumnya, dalam kedua aspek tersebut sistem PV memiliki efisiensi dan akurasi yang baik. Selain kedua faktor tersebut, sistem juga harus bekerja secara responsif. Sistem harus dapat mengikuti perubahan yang ada, dalam hal ini perubahan suhu dan irradiasi. Ketika terjadi 
perubahan suhu atau perubahan irradiasi, sistem harus dapat mengikutinya sehingga daya optimal selalu di dapatkan.

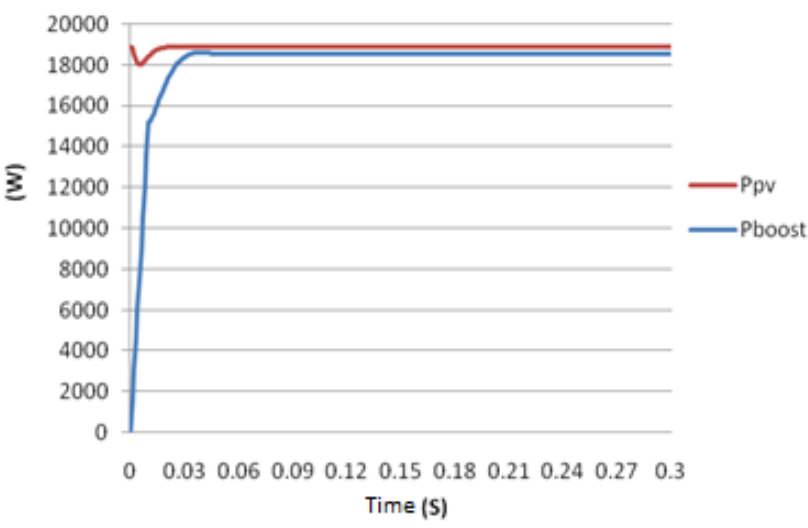

Gambar 11. Grafik fungsi daya PV dan boost konverter.

Gambar 12 mensimulasikan tanggapan sistem PV terhadap perubahan irradiasi. Perubahan irradiasi dari $1000 \mathrm{~W} / \mathrm{m}^{2}$ menjadi $500 \mathrm{~W} / \mathrm{m}^{2}$ terjadi pada waktu sama dengan satu sekon. Dari grafik dapat kita amati bahwa ketika terjadi perubahan irradiasi MPPT segera bekerja sehingga titik daya maksimum tidak terlepas. Daari grafik dapat kita simpulkan bahwa sistem PV mempunyai tanggapan yang baik. Dapat diamati pada saat Irradiasi 1000 $\mathrm{W} / \mathrm{m}^{2}$ daya baterai bernilai positif yang berarti baterai menyimpan daya atau charging. Ketika Irradiasi bernilai $500 \mathrm{~W} / \mathrm{m}^{2}$ daya baterai bernilai negatif yang menunjukkan bahwa baterai mengalami discharging. Baterai menyimpan daya ketika daya yang dihasilkan berlebih, sebaliknya ketika daya yang dihasilkan PV lebih sedikit dibandingkan kebutuhan inverter, maka baterai akan mengalami discharging. Dari grafik tersebut dapat disimpulkan bahwa baterai sudah dapat bekerja dengan benar.

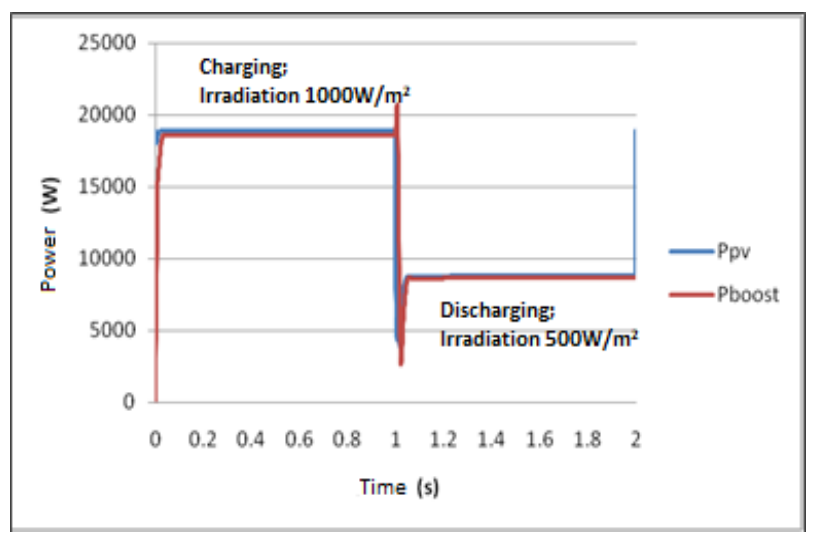

Gambar 12. Grafik fungsi daya terhadap waktu

\subsection{Tingkat Akurasi Sistem PV}

Tingkat akurasi sistem PV tentu sangat dipengaruhi oleh kontroler di dalamnya. Kontroler yang berfungsi mendapatkan tegangan referensi Vref merupakan komponen yang paling berpengaruh dalam tingkat akurasi sistem pada penelitian ini. Tabel 2 menyajikan data akurasi Vref yang dihasilkan oleh Neuro fuzzy. Akurasi nilai Vref berbeda-beda pada variasi irradiasi $100 \mathrm{~s} / \mathrm{d}$ $1000 \mathrm{~W} / \mathrm{m}^{2}$. Nilai akurasi rata-rata Vref untuk variasi nilai irradiasi $100 \mathrm{~s} / \mathrm{d} 1000 \mathrm{~W} / \mathrm{m}^{2}$ dan temperatur $35{ }^{\circ} \mathrm{C}$ bernilai $99,78 \%$. Nilai $99,78 \%$ menunjukkan sistem memiliki akurasi yang sangat baik.

Tabel 2. Akurasi Tegangan Vref pada suhu $35^{\circ} \mathrm{C}$ dengan variasi irradiasi $100 \mathrm{~s} / \mathrm{d} 1000 \mathrm{~W} / \mathrm{m}^{2}$

\begin{tabular}{|l|l|l|l|l|l|}
\hline $\begin{array}{l}\text { Suhu } \\
\left({ }^{\circ} \mathrm{C}\right)\end{array}$ & $\begin{array}{l}\text { Irrad } \\
\left(\mathrm{W} / \mathrm{m}^{2}\right)\end{array}$ & $\begin{array}{l}\text { Vref } \\
(\mathrm{V})\end{array}$ & $\begin{array}{l}\mathrm{Vpv} \\
(\mathrm{V})\end{array}$ & $\begin{array}{l}\text { Error } \\
(\mathrm{V})\end{array}$ & $\begin{array}{l}\text { Acc. } \\
\text { Vref }\end{array}$ \\
\hline 35 & 1000 & 263.7 & 263.4 & 0.3 & $99.89 \%$ \\
\hline 35 & 900 & 261.3 & 261.7 & 0.4 & $99.85 \%$ \\
\hline 35 & 800 & 259.4 & 259.7 & 0.3 & $99.88 \%$ \\
\hline 35 & 700 & 257.7 & 257.15 & 0.55 & $99.79 \%$ \\
\hline 35 & 600 & 255 & 254.1 & 0.9 & $99.65 \%$ \\
\hline 35 & 500 & 249.9 & 250.25 & 0.35 & $99.86 \%$ \\
\hline 35 & 400 & 245.8 & 245.3 & 0.5 & $99.80 \%$ \\
\hline 35 & 300 & 238.6 & 238.55 & 0.05 & $99.98 \%$ \\
\hline 35 & 200 & 228.3 & 228.6 & 0.3 & $99.87 \%$ \\
\hline 35 & 100 & 211.6 & 210 & 1.6 & $99.24 \%$ \\
\hline
\end{tabular}

Sedangkan Tabel 3 menyajikan data akurasi Vref yang dihasilkan oleh Neuro fuzzy. Akurasi nilai Vref berbeda-beda pada variasi suhu $25 \mathrm{~s} / \mathrm{d} 50$ ${ }^{\circ} \mathrm{C}$. Nilai akurasi rata-rata Vref untuk variasi nilai suhu $25 \mathrm{~s} / \mathrm{d} 50{ }^{\circ} \mathrm{C}$ dan irradiasi 800 bernilai 99.84 $\%$. Nilai $99,84 \%$ menunjukkan sistem memiliki akurasi yang sangat baik.

Tabel 3. Akurasi tegangan referensi Vref pada irradiasi $1000 \mathrm{~W} / \mathrm{m}^{2}$ dengan variasi suhu $25 \mathrm{~s} / \mathrm{d} 50{ }^{\circ} \mathrm{C}$

\begin{tabular}{|l|l|l|l|l|l|}
\hline $\begin{array}{l}\text { Suhu } \\
\left({ }^{\circ} \mathrm{C}\right)\end{array}$ & $\begin{array}{l}\text { Irrad } \\
\left(\mathrm{W} / \mathrm{m}^{2}\right)\end{array}$ & $\begin{array}{l}\text { Vref } \\
(\mathrm{V})\end{array}$ & $\begin{array}{l}\text { Vpv } \\
(\mathrm{p}=\max ) \\
(\mathrm{V})\end{array}$ & $\begin{array}{l}\text { Error } \\
(\mathrm{V})\end{array}$ & $\begin{array}{l}\text { Akurasi } \\
\text { Vref }\end{array}$ \\
\hline 25 & 800 & 270.5 & 271 & 0.5 & $99.82 \%$ \\
\hline 30 & 800 & 265 & 265.3 & 0.3 & $99.89 \%$ \\
\hline 35 & 800 & 259.7 & 259.4 & 0.3 & $99.88 \%$ \\
\hline 40 & 800 & 254.1 & 254 & 0.1 & $99.96 \%$ \\
\hline 45 & 800 & 248.4 & 248.4 & 0 & $100.00 \%$ \\
\hline 50 & 800 & 244.3 & 243 & 1.3 & $99.47 \%$ \\
\hline
\end{tabular}


Dalam studi ini, rata-rata panel surya PV di area kampus universitas muhammadiyah malang (UMM) dipilih sebagai studi kasus. Gambar 13 menyajikan daya PV rata-rata setiap bulan untuk area kampus UMM 3 sebagai studi kasus. Iradiasi rata-rata tertinggi terjadi pada bulan Februari dan Oktober, sedangkan iradiasi rata-rata terkecil terjadi pada bulan Juni.

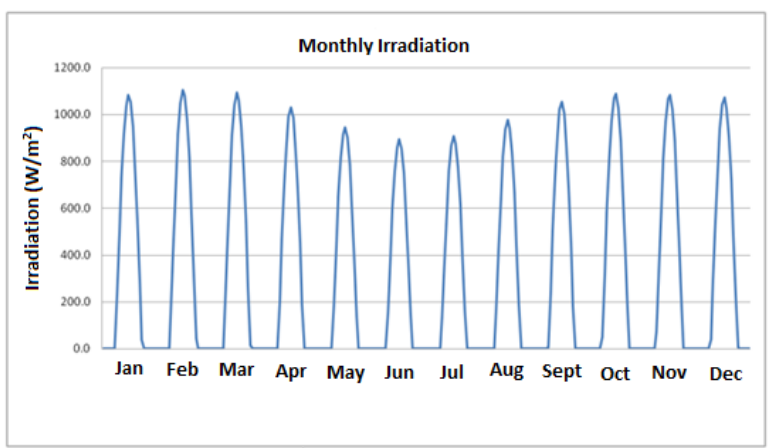

Gambar 13. Irradiasi rata-rata setiap bulan di area kampus 3 UMM

Dari data grafik tersebut, didapat besar Irradiasi rata-rata per bulan sebesar $1069.5 \mathrm{Wh} / \mathrm{m}^{2}$. Dengan efisiensi rata-rata sistem PV sebesar $12 \%$ maka daya ratarata per bulan yang dapat dihasilkan oleh sistem sebesar $18.472 \mathrm{KWh}(1069.5 * 145.152 *$ $12 \% \mathrm{Wh})$.

\section{Kesimpulan}

Pengukuran rata-rata bulanan sistem tenaga PV iradiasi telah dilakukan dengan area UMM-3 sebagai studi kasus dalam pekerjaan ini. Dapat dialamatkan beberapa kesimpulan yang meliputi; (i) Daya yang dihasilkan oleh PV tergantung pada jumlah iradiasi yang diterima. (ii) Semakin tinggi nilai iradiasi, daya output juga akan meningkat. (iii) Daya keluaran panel surya berbanding terbalik dengan perubahan suhu. Dan (iv) sudut anggukan kanan akan memengaruhi nilai iradiasi yang diterima oleh panel surya.

Saran lebih lanjut adalah hal penting yang bisa menjadi referensi untuk pengembangan. Perlu diuji secara real time sehingga Anda dapat mengetahui kinerja sistem secara keseluruhan.

\section{Ucapan Terima Kasih (Acknowledgement)}

Penulis mengucapkan terima kasih yang sebesar-besarnya kepada Direktorat Penelitian dan Pengabdian Masyarakat (DPPM), Universitas
Muhammadiyah Malang untuk terus mendukung dan membiayai penelitian ini.

\section{Daftar Pustaka}

[1] M. M. Arturo and G. P. Alejandro, "High Precision Solar Tracking System," in Proceedings of the World Congress on Engineering, 2010, vol. 2, pp. 2-4.

[2] A. Ponniran and H. A. Munir, "A Design of Single Axis Sun Tracking System," in International Power Engineering and Optimization Conference (PEOCO2011), 2011, no. June, pp. 107-110.

[3] D. Mereddy, V. R. R. V, and T. Sadula, "Smart Dual Axes Solar tracking," in 2015 International Conference on Energy Systems and Applications, 2015, no. 978, pp. 370-374.

[4] A. El Hammoumi and A. El Ghzizal, "A simple and low- - cost active dual- - axis solar tracker," Energy Sci. Eng., vol. 6, pp. 607-620, 2018.

[5] J. Wang and C. Lu, "Design and Implementation of a Sun Tracker with a Dual-Axis Single Motor for an Optical Sensor-Based Photovoltaic System," Sensors, vol. 13, pp. 3157-3168, 2013.

[6] H. Mousazadeh, A. Keyhani, A. Javadi, H. Mobli, K. Abrinia, and A. Sharifi, "A review of principle and sun-tracking methods for maximizing solar systems output," Renew. Sustain. Energy Rev., vol. 13, pp. 1800-1818, 2009.

[7] M. Jamilu, "A Review on Solar Tracking Systems and Their Classifications," $J$. Energy, Environ. Chem. Eng., vol. 2, no. 3, pp. 46-50, 2017.

[8] L. Z. Yi et al., "Development of Algorithm for Single Axis Sun Tracking System," in International Conference on Fundamental and Applied Sciences (ICFAS2016), 2016, vol. 2016, pp. 1-9.

[9] B. Toual, L. Mokrani, A. Kouzou, and M. Machmoum, "Control And Management Of A Solar-Wind Hybrid System For Power Quality Improvement," J. Eng. Sci. Technol., vol. 13, no. 6, pp. 1420-1439, 2018.

[10] M. Engin and D. G. Engin, "Optimization Controller for Mechatronic Sun Tracking System to Improve Performance," $A d v$. Mech. Eng., vol. 2013, pp. 1-9, 2013. 
[11] J. S. Jang Roger, "ANFIS: AdaptiveNetwork-Based Fuzzy Inference System," IEEE Trans. Syst. Man Cybern., vol. 23, no. 3, pp. 665-685, 1993.

[12] L. I. Kuncheva, Fuzzy Classifier Design. Springer Berlin Heidelberg, 2012.

\section{Biodata Penulis}

Muhammad Irfan, adalah peneliti dan juga Dosen di Fakultas Teknik, Universitas Muhammadiyah Malang. Lulus Magister Teknik, di Jurusan Teknik Informatika, Institut Teknologi Sepuluh Nopember (ITS), Surabaya pada tahun 2000. Saat ini juga aktif sebagai Kepala Divisi Pengabdian Masyarakat di Direktorat Penelitian dan Pengabdian Masyarakat, Universitas Muhammadiyah Malang. Minat penelitian saat ini tentang Sistem Elektronika, Tenaga Listrik dan Energi Terbarukan.

Ilham Pakaya, merupakan peneliti dan Dosen di Jurusan Teknik Elektro, Fakultas Teknik Universitas Muhammadiyah Malang. Lulus Magister Teknik Terapan, di Politeknik Negeri Malang pada tahun 2019. Saat ini sedang mendalami penelitian pada bidang Sistem Tenaga Listrik.

Amrul Faruq, adalah peneliti dan Dosen di Jurusan Teknik Elektro, Fakultas Teknik Universitas Muhammadiyah Malang. Lulus Master of Engineering dari Universiti Teknologi Malaysia (UTM) pada tahun 2013. Saat ini fokus penelitian pada data analisis dan optimalisasi sistem. 